ownership of the samples passes to the WHO collaborating centres, and that it does not benefit from any resulting papers or patents.

Indonesia says it will share samples under a material transfer agreement that allows research use, but gives Indonesia sovereign ownership of the samples. The country also wants access to vaccines developed using its samples. An international meeting on 20-23 November in Geneva, Switzerland, ended without agreement. But a statement, still being thrashed out by negotiators, is expected to open the way to concessions.

Indonesia has had the most deaths from the H5N1 bird-flu virus of any country -91 so far - the most recent on 6 November.

\section{China secures contract for Afghan copper mine}

Afghanistan last week announced that a Chinese firm has won the bid for the first post-Taliban natural-resource development project: the US\$30-billion Aynak copper deposit outside Kabul (see Nature 449, 968-971; 2007).

The state-owned China Metallurgical Group will now negotiate the final terms of the deal, in which China is pledging $\$ 2.9$ billion to Afghanistan to create a mine in five years that will tap the

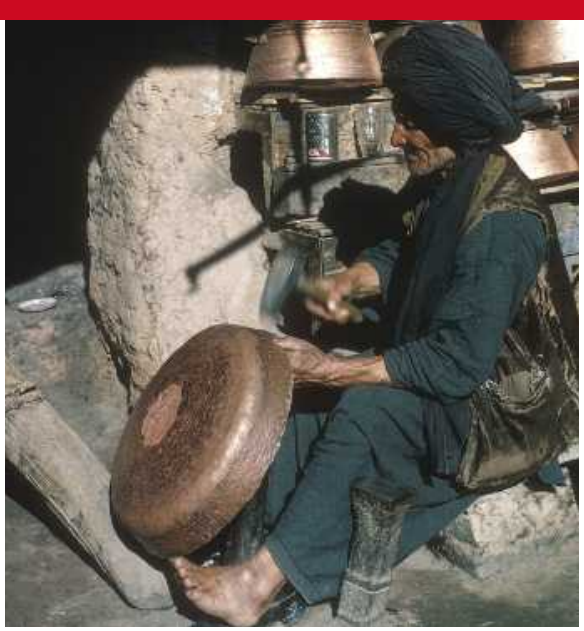

Afghanistan's rich copper resources are set to be mined by a Chinese company.

estimated 13 million tonnes of ore.

China's operation of Aynak will be closely watched by scientists, aid agencies and economists because of environmental and socio-economic concerns raised over mining projects elsewhere.

\section{India commits to boosting biotechnology research}

For the first time, India has appointed a biologist as head of its largest research agency. The announcement coincides with the unveiling of a national strategy for biotechnology, supported by a 65 -billionrupee (US\$1.6-billion) commitment over the next 5 years.

Samir Brahmachari, former director of the Institute of Genomics and Integrative Biology in Delhi, is the new chief of the Council of Scientific and Industrial Research (CSIR). The CSIR manages 41 labs with a staff of more than 18,000 scientists and has been without a permanent director since December 2006 (see Nature 447, 238-239; 2007).

The strategy approved by the cabinet on 14 November calls for one-third of the government's research budget to be spent on biotechnology - a $450 \%$ increase over the previous 5 years - in partnership with private-sector funding. The plan will create 50 biotech 'centres of excellence' by 2012 .

\section{Correction}

The News story 'Field trials aim to tackle poverty' (Nature 449, 957; 2007) implied that the idea of using mobile-phone-based reminders and time-based incentives to improve tuberculosis drug-regimen adherence originated at the Abdul Latif Jameel Poverty Action Lab at the Massachusetts Institute of Technology (MIT). In fact, the idea came from Viji Draviam of Harvard Medical School and Nishanth Sastry of MIT and the University of Cambridge, UK. 